\title{
Effect of Aflatoxin Contaminated Feed On Energy Reserves of Fish Labeo rohita (Hamilton)
}

\author{
DURRE SHAHWAR RUBY 1 , AHMAD MASOOD² and AMJAD FATMI ${ }^{3}$ \\ ${ }^{1}$ Department of Zoology, B.S Coldanapur,Patna, 800012, Bihar, India. \\ ${ }^{2}$ Department of Botan, H.D. Jain College Ara- 802301, India. \\ 3Department of Zoology, Govt. P.G College, Dholpur- 328001, Rajasthan, India.
}

http://dx.doi.org/10.12944/CWE.9.3.60

(Received: August 17, 2014; Accepted: September 12, 2014)

\begin{abstract}
Effect of aflatoxin contaminated feed on glycogen content ofliver,blood glucose, total serum protein and blood urea of the fish Labeo rohita was studied. The result revealed that administration of aflatoxin decreased liver glycogen and tatal serum protein but blood level of glucose and urea increased.
\end{abstract}

Key words: Aflatoxin, Labeo rohita, Blood glucose

\section{INTRODUCTION}

In Teleost the level of glucose and protein is an indicator of stress in fishes. The major source of blood glucose is liver glycogen. The level ofurea in blood indicates the degree of damage to kidney and utilization of protein in the body. Aflatoxin is the metabolic by product of molds Aspergillus flavus and Aspergillus parasiticus on a variety of food such as cotton seed, corn, wheat, milk, fish meal etc.lt is a toxic compound, a potent immunosuppressive and carcinogenic agent and the cause of high mortality in livestock, (Reed and Kasali., 1987, Montessano et al.,1997). Due to growth requirement of the molds aflatoxin poses a greater risk in warmer climate. Effects of aflatoxin on fishes and other animals have been reported by many workers. Nunez et al. (1991) reported hepatocellular adenoma and hepatocellular carcinoma in Rainbow trout when exposed to aflaroxin $B_{1}$. Caguan et al. (2004) reported loss of appetite, low survival percent and decreased mean total biomass in tilapia when fed with aflatoxin contaminated feed. Faisal et al. (2008) reported spermatotoxic effect of aflatoxin in male wister rat.Aflatoxin causes elevated blood glucose level in aflatoxin treated Nile Tilapia (El-Boshy et al., 2008). The extent of damage produced by aflatoxin depends upon the species, the toxin concentration and time period of the exposure(Coulombe et al., 1984; Centroducati et al., 2009; Sepahdari et al., 2010).In the present investigation effect of aflatoxin on glycogen content of liver, blood glucose level, total serum protein and blood urea level of Labeo rohita has been evaluated in order to explore the effect of toxin in the fish.

\section{MATERIALS AND METHODS}

The fish Labeo rohita was collected from river sone near Ara. 72 fishes measuring about10 -20 $\mathrm{cm}$ and weighing about $30-50 \mathrm{gm}$ were selected and kept in twelve aquaria measuring $3^{1} \times 2^{1} \times 1^{1}$. Six fishes were kept in each aquarium. Three aquaria containing six fishes each were kept as control and nine aquaria containing six fishes each were kept as experimental set.

\section{Four feeds were employed as follows}

- $\quad$ Feed I or good feed contained $0 \%$ moldy feed or unmixed feed. Feed I were given to control.

- $\quad$ Feed II contained $10 \%$ moldy feed and $90 \%$ good feed. Feed II were given to first set of 
experimental fishes comprising aquaria $2 \mathrm{~A}$, $2 \mathrm{~B}$ and $2 \mathrm{C}$.

- $\quad$ Feed III contained $50 \%$ good feed and $50 \%$ moldy feed. Feed III were given to second set of experimental fishes comprising three aquaria $3 \mathrm{~A}, 3 \mathrm{~B}$ and $3 \mathrm{C}$.

- $\quad$ Feed IV contained $100 \%$ moldy feed. Feed IV were given to fourth set of fishes comprising three aquaria $4 \mathrm{~A}, 4 \mathrm{~B}$ and $4 \mathrm{C}$.

Moldy feed were prepared in laboratory. The commercial fish feed was first sprinkled with small amount of tap water to make the feed moist and then infected with cultured Aspergillus flavus by mixing 10 $\mathrm{ml}$ of cultured Aspergillusflavus. The inoculation was made in a transfer chamber to avoid contamination. The mixed feed was then covered with a plastic sack. The infected feed was kept in a condition which is favourable for the growth of mold.

Required amount of moldy feed and good feed were weight carefully for each treatment and then mixed thoroughly. The fish were fed a day after and daily there after two times a day at $8.00 \mathrm{am}$ and at $6.00 \mathrm{pm}$ at a feeding rate of $4 \%$ of the body weight .

The quantitative estimation of glycogen content of liver was estimated according to a modified method of Kemp and Andrein (1954). Blood glucose was estimated by O. Toluidine method of Cooper and McDanile (1970). Quantitative estimation of total serum protein was done according to the method of Kinsley (1942) followed by Mehl (1945) and Weichselbaum (1946).Blood urea was quantitatively estimated according to the Phenol hypochlirite method using the Berthelot Reaction (Fawcet and Scott 1960; Chaney and Marbach 1962).

\section{RESULT AND DISCUSSION}

The glycogen content of liver was 31.9 $\pm 0.24 \mathrm{mg} / \mathrm{g}$ in control and that of experimental fish fed with feed IV $(100 \%$ moldy feed $)$ was $22.0 \pm 0.24$ $\mathrm{mg} / \mathrm{g}$. The blood glucose level was observed as $71.5 \pm 0.69 \mathrm{mg} / 100 \mathrm{ml}$ in control and $101.3 \pm 1.49$ $\mathrm{mg} / 100 \mathrm{ml}$ in fishes given feed IV. Thus there was a significant $(p>0.05)$ and gradual decline in the content of liver glycogen and a simultaneous rise in the blood glucose observed in the experiment fish when aflatoxin contamination increased in the food. Thus the present findings are in agreement with those of Nunez et al.(1991)in Oreochromis mykiss ,El- Boshy et al.(2008) Cicik and Engin (2005) reported depletion of liver and muscle glycogen in Cyprinus carpio under the condition of stress, when it is utilized for detoxification process. Nunez et al. (1991) reported increased glycogen catabolism through glycogenolysis and pentose phosphate pathways having hepatocellular carcinoma and hepatocellular adenoma when exposed to aflatoxin. El- boshyet al. (2008)reported increased blood glucose level in aflatoxin treated Oreochromis niloticus.

Blood glucose level closely correlate to stress level in fish and represent the state of respiratory and nutritional disturbance(Hideaki., 2009; Porchse et al.,2009; Mehmet and Sen., 2011). Zaki (2012) reported significant increase in cortisol level and significant decrease in insulin level in aflatoxin treated fish Clariuslazera. An increase in cortisol level increases glycogenolysis in liver. In the present investigation liver glycogen level is low and blood glucose level is high in fishes fed with aflatoxin contaminated feed which indicates that the increase in blood glucose level is probably due to increased liver glycogenolysis. Also the increase in blood glucose level may also be attributed to decrease in secretion of insulin as an effect of aflatoxin, which in turn reduces the process of glycogensis resulting in rise of blood glucose level. In addition the rise in blood glucose many also be due to gluconeogenic breakdown of protein to form glucose for energy production to be utilized in detoxification process at the time of stress induced by aflatoxin.

Thus in the present investigation depletion of liver glycogen and increase in blood glucose might have resulted due to increased glycogenolyis, gluconeogenesis and decreased glycogenesis as an effect of dietary aflatoxin mediated by increased cortsol and decreasedinsulin level under the condition of stress.

In the present study there was a gradual fall in total serum protein and a simultaneous rise in the blood urea level with the increase in the aflatoxin contaminated feed in the food. The present findings are in agreement with Pepeljnjak et al.(2003) 


\begin{tabular}{lcccc} 
Treatments & Feed I & Feed II & Feed III & Feed IV \\
\hline Liverglycogen $(\mathrm{mg} / \mathrm{g})$ & $31.9 \pm 0.24$ & $30.5 \pm 0.23$ & $25.7 \pm 0.25$ & $22.0 \pm 0.24$ \\
BloodGlucose $(\mathrm{mg} / 100 \mathrm{ml})$ & $71.5 \pm 0.69$ & $77.4 \pm 0.64$ & $87.2 \pm 1.08$ & $101.3 \pm 1.49$ \\
Bloodurea(mg/100ml) & $2.40 \pm 0.01$ & $2.86 \pm 0.01$ & $3.42 \pm 0.01$ & $4.57 \pm 0.04$ \\
TotalSerum Protein $(\mathrm{mg} / 100 \mathrm{ml})$ & $4.33 \pm 0.10$ & $3.93 \pm 0.04$ & $3.59 \pm 0.02$ & $3.20 \pm 0.02$ \\
\hline
\end{tabular}

inrainbow trout,El-Boshy at al. (2008) and Shehata at al.(2009) in O.niloticus.Martinez et al. (2004) reported that fish under stress may mobilize protein to meet energy requirement needed to sustain increase physiological activities.

Since fishes have a very little amount of carbohydrate ( Rao, 1999), the next alternative source of energy is protein to meet the increased energy demand under the condition of stress.Buhlar et al. (2000) reported that exposure to mycotoxin decreases protein synthesis in Onchorhynchus mykiss.Aflatoxin causes loss of appetite resulted in hypophagia and this might have also caused the decrease in total serum protein level.

The serum urea level showed an increase with increase in aflatoxin contaminated feed. A rise in Bllood urea level indicates to abnormal kidney function(Newberne 1981). Similar findings were reported by Zaki et al. $(2008,2010)$ in aflatoxin treated fishes Tilapia nilotica and Tilapia zilli . Increase in urea level due to necrosis in kidney was reported by Mansfeld (1989), Pier(1987). Thus in the present studies aflatoxin might have caused necrosis in kidney resulting in increase in urea level.

\section{REFERENCES}

1. Buhler, D.R., Miranda.C.L., Henderson.M.C ., Yang,Y.H ., Lee,S.J and Buhler,W.J.L. Effects of 17 beta estradiol and testosterone on hepatic MRNA \ protein levels and calalytic activities of CYP2M1, CYP2K1 and CYP3A27 in rainbow trout (Oncorhynchus mykiss) . Toxico. Appl. Pharmacol.; 168 (2): 91-101 (2000).

2. Cicik,B and Engin,K. The effect of cadmium on levels of glucose in serum and glycogen reserves in liver and muscle tissue of Cyprinus carpio (L. 1758) . Turk. J. Vet. Anim. Sci. 29; 113-117 (2005).

3. Caguan, A .G., Tayaban,R.H ., J.R. Somga and Bartolome,R.M. Effect of Aflatoxin Contaminated feed in Nile tilapia (Oreochromis niloticus L.). In Proceeding of the $6^{\text {th }}$ International symposium on tilapia in aquaculture (R.B. Remedios, G.C. Imir and K. Fitzsimons. eds.). pp :172 - 178 (2004).

4. Centroducati, G., Shantacroce. M.P., Lestingi . A., Casalino. E., Crescenzo, G. Characterization of cellular damage induced by aflatoxin B1 in Sea bream (Sparus aurata L. 1758.) hepatocytes. Ital. J. Anim. Sci., 8: 848-850 (2009).
5. Coulombe, R. A Jr., Bailey, G.S., Nixon,J.E. Comparative activation of aflatoxin $B_{1}$ to mutagens by isolated hepatocytes from rainbow trout (Salmo gaurdneri) and coho salmon (Oncorhynchus Kisutch). Carcinogenesis,5: 29-33 (1984).

6. Cooper, G.R and McDanile,V. Manual of routine methods in clinical chemistry for use in intermediate laboratory. Std. Methods. Clin. Chem. 6: 159-70 (1970).

7. El-Boshy, M.E.,A. M.M.EL- Ashram and Nadia A. Abdel Ghany. Effect of dietary beta-1, 3, glucan on immunomodulation on deseased Oreochromis niloticus experimentally infected with aflatoxin $B_{1}$. $8^{\text {thinternational symposium }}$ on tilapia in aquaculture 2008.

8. Faisal. K ., perisamy , V. S., Sahabuddin ,S., Radha , A., Anandhi ,R and Akbarsha , M. A. Spermatotoxic effect of aflatoxin $B_{1}$ in rat : extrusion of outer dense fibers and associated axonemal microtubule doublets of sperm flagellum. J. Soci. Repro. Fert. 135: 303-310 (2008).

9. Fawcet and Scot, Chaney and Marbach.1962. in "Practical clinical biochemistry", (Ed.) Varley, H: 160-161 (1960). 
10. Hiddeaki,E., Yuki,Y., Kyoko, H., Huifeng, R., Tetsuhito, H., Wakako, T and Koji,S. Wireless enzyme sensor system for real time monitoring of blood glucose level in fish. Biosensor.Bioelectronics; 24(1). pp : 14171423 (2009).

11. Kemp. A and Andrienne,J.M.K.V.H. A colorimetric micro method for the determination of glycogen in tissue. Biochem. J. 56: 646-648 (1954).

12. Kingsley. A colori metric method of blood analysis in "Hawk's physiological chemistry" Oser. B.L. (ed.) Tata Mcgraw-Hill. New Delhi (1942).

13. Mansfeld, R., Graoert, E and Kautna, J. Mycotoxicosis a problem of diary cowherd. Monalshelfl fur Velerenal medizin, 44: 409 (1989).

14. Mehl, O. A. colorimetric method of blood analysis. In "Hawks physiological chemistry". Oser. B.L. (Ed.) .Tata Mc Graw-Hill New Delhi (1945).

15. Martinez, C.B.R; Nagae, M.Y; zaia, C.T.B. V; zaia D.A.M. Morphological and physiological acute effect of lead in the neotropical fish prochilodus lineatus. Braz. J. Biol; 64: 797-807 (2004).

16. Mehmet, Z. C. and Sen, D. Examination of liver and muscle glycogen and blood glucose levels of Capoeta umbla (Hekel, 1943) living in Hazare lake and Keban Dam lake (Elazig, Turkey) .Afric. J. Biotech. 10(50), pp : 10271 10279 (2011).

17. Montesano,R; Hainut, P;Wild,C.P. Hepatocellular carcinoma : From gene to public health review. J.Nat. Cancer Inst. 89: 1844-1851 (1997).

18. Newberne, P.M and Rogers,A.E. Animal toxicity of major environmental toxins. In "Shank R.C. ed. Mycotoxins and N-Nitroso Compounds. Environmental risk Vol.I.CRC Press Inc. Florida, 51-197 (1981).

19. Nunez. J.D.H;Hendricks, J. D; Duimishra, J.R. Ultra structure of hepato cellular neoplasms in aflatoxin $\mathrm{B}_{1}\left(\mathrm{AFB}_{1}\right)$ initiated rainbow trout (Oncorhychus mykiss). Toxicol Pathol. 19 (i) pp-11-21 (1991).
20. Pepeljnjak,S.,Petrinec,Z.,Kovac,S. And segvic, M.92003) Screening toxicity study in young carp(cyprinus carpio L.) on feed amended withfumonisin B1. Mycopathologia. 156 (2) :11-21.

21. Pier, A.C.Aflatoxicosis and immunosuppression in mammalian animals. In M.S. Zuber; Leelehoj,G.B and Rossitor,B.L. (ed). Aflatoxin in man. Cimmyt. Maxico, 65 (1987).

22. Porchas. M. M.,Cordova, M.L.F and Enriquez,R.R. Cortisol and glucose; reliable indicators of fish stress. Pan- Am. J.Aq. Sci., 4(2) :158-178 (2009).

23. Reed,J.D;Casali,O.B. Hazards to livestock consuming aflatoxin contaminated meal in Africa. In: ICRISAT proceeding of international workshop on aflatoxin contamination in ground nut. 6-9 Oct.1986 (1987).

24. Rao,S.K.R.S. (1999) pesticide impact on fish metabolism. Discovery Publishing House. New Delhi, India. pp: 66-70.

25. Weichselbaum, C. An improved procedure of protein estimation by Biuret reagent method J. Clin. Pathol. 7: 40-43 (1946).

26. Sepahdari,A.,Ebrahinzadeh,M. H. A., Sharif, P.I.,Khosravi,A., Motalebi, A.A.,Mohseni, M.,Kakoolaki, S., :Pourali, H. R. andHallajian, A. Effect of different dietary level of AFB1 on survival rate and growth factor of Beluga(Huso huso).I. J. Fish. Sci. 9(1): 141-150 (2010).

27. Shehata, S.A., Melegi, E.L.K.H.M., Ibrahim, M.S. Aflatoxicity reduction of aflatoxin B1 by vit. $\mathrm{C}$ in fish. J. Arabian Aquaculture Society. 4(2):73-82 (2009).

28. Zaki, M.s.,Sharaf,N.E., rashad,H., Mustafa ,S.O and Fawzi, O.M. Diminution effect of aflatoxicosis in tilapia nilotica fish by dietary supplementation of fix in toxin and Nigella sativa oil. Am.Eur. Agr.Env. Sci. 3(2): 2011 2015 (2008).

29. Zaki, M.S.,fawzi, O. M.,Omar,S.,Khafagi,M., and Awadi, I. Diminution effect of aflatoxicosis in Tilapia zilli fish by dietary supplementation of fix in toxin and Nigella sativa. Nature and Science. 8(2) : 43-49 (2010).

30. Zaki, M. S. Effect of aflatoxin on endocrine status in cat fish (Clarius lazera). Life sci. $j$. 9(1): 419-422 (2012). 